\title{
KEMAMPUAN KOPING DENGAN TINGKAT KECEMASAN KLIEN HIPERTENSI
}

\author{
Jubaedah $^{1}$, Ayu Pratiwi ${ }^{2}$ \\ 1,2 Prodi Ilmu Keperawatan STIKes Yatsi, Tangerang \\ Jl. Aria Santika No. 40A, RT 005/RW011 Margasari, Kec. Karawaci, Kota Tangerang, \\ Banten, Indonesia \\ Nyonyajubaidah@gmail.com
}

\begin{abstract}
Abstrak
Hipertensi memiliki sebutan silent killer karena sering menimbulkan komplikasi pada organ lain tanpa ada gejala, hal tersebut sering menimbulkan kecemasan pada penderita hipertensi. Koping adalah usaha dalam mengatasi stres psikologis termasuk kecemasan. Penelitian ini bertujuan untuk mengetahui hubungan kemampuan koping dengan tingkat kecemasan pada penderita. Desain penelitian ini adalah penelitian korelasional dengan pendekatan studi cross sectional dengan sampel penelitian sebanyak 100 responden diambil dengan teknik total sampling. Hasil penelitian menunjukkan bahwa gambaran penderita hipertensi di Wilayah Kerja Puskesmas Grogol Kota Cilegon mayoritas berusia $\geq 45$ tahun (63\%), mayoritas berjenis kelamin laki-laki $(67 \%)$, mayoritas menderita hipertensi $\geq 5$ tahun $(60 \%)$, mayoritas memiliki kemampuan koping maladaptif $(65 \%)$ dan mayoritas mengalami cemas sedang (43\%). Ada hubungan signifikan antara kemampuan koping dengan kecemasan pada penderita hipertensi di Wilayah Kerja Puskesmas Grogol Kota Cilegon tahun 2021 (p value: 0,000$)$.
\end{abstract}

Kata kunci : hipertensi, kecemasan, koping

\begin{abstract}
Hypertension is often called the silent killer because it is often asymptomatic and causes complications in other organs, this often causes anxiety in people with hypertension. Coping is an attempt to overcome psychological stress, including anxiety. The purpose of this study was to determine the relationship between coping abilities and anxiety levels in patients with hypertension. The design of this study was a correlational study with a cross-sectional study approach with a sample of 100 respondents taken using a total sampling technique. The results showed that the description of hypertension sufferers in the Grogol Health Center Work Area, Cilegon City, the majority aged 45 years $(63 \%)$, the majority were male (67\%), the majority suffered from hypertension 5 years $(60 \%)$, the majority had coping skills. maladaptive (65\%) and the majority experienced moderate anxiety (43\%). There is a significant relationship between coping abilities and anxiety in patients with hypertension in the Grogol Health Center Work Area, Cilegon City in 2021 ( $p$ value: 0.000).
\end{abstract}

Keywords: hypertension, anxiety, coping

\section{PENDAHULUAN}

Hipertensi memiliki sebutan silent killer karena terjadinya sering tanpa gejala bahkan bisa menjadi parah dan menimbulkan penyakit pada organ lain (Lewis, 2011). Hipertensi merupakan nilai TD sistolik melebihi 140 $\mathrm{mmHg}$ dan TD diastolik melebihi $90 \mathrm{mmHg}$ (Nurarif \& Kusuma, 2015).

Menurut survei WHO (2013) di seluruh dunia sebanyak 1 milyar orang menderita tekanan darah tinggi dan tahun 2025 diperkirakan mencapai 1,5 milyar orang. Di Indonesia dan juga negara-negara berkembang lainnya, prevalensi hipertensi mencapai 65 juta penderita atau 65,74\% (Tamako, 2016). Prevalensi hipertensi tertinggi pada perempuan sebesar $(36,85 \%)$ sedangkan laki-laki $(31,34 \%)$ (Kemenkes RI, 2018).

Salah satu masalah pada hipertensi adalah timbulnya gangguan psikologis seperti

Corresponding author:

Jubaedah

Nyonyajubaidah@gmail.com 
kecemasan. Terdapat dua gejala pada kecemasan yaitu gejala fisiologis seperti detak jantung bertambah cepat, sakit kepala, pencernaan tidak teratur, tidak nafsu makan, insomnia, nafas sesak, keringat bercucuran, ujung jari terasa dingin, dan gejala psikologis seperti perasaan khawatir, takut, tidak mampu berkonsentrasi, tidak percaya diri, gelisah, dan bingung (Lesmana, 2014).

Kecemasan terjadi akibat respon pada kejadian di masa lalu atau yang akan datang. Makin besar ancaman maka kecemasan yang dirasakan juga makin besar. Respon kecemasan pada individu bervariasi, yaitu respon adaptif yang merespon kecemasan dengan motivasi tinggi yang dapat menimbulkan problem solving produktif, dan respon maladaptif yaitu kecemasan tidak membantu mengatasi masalah dan bahkan memperburuk keadaan (Ridwan et al., 2017).

Koping merupakan usaha individu untuk mengatasi stres psikologis. Jika koping penderita hipertensi tidak baik akan menyebabkan rasa cemas, takut, stres dan nyeri yang bisa menyebabkan stimulasi simpatik sehingga memicu peningkatan tekanan darah, curah jantung, dan frekuensi perifer (Kozier \& Barbara, 2011). Koping dinyatakan berhasil apabila dapat menurunkan detak jantung, tekanan darah, detak nadi serta sistem pernafasan (Abdul \& Abdul, 2011).

\section{METODE PENELITIAN}

Penelitian ini merupakan penelitian deskriptif korelasional dengan pendekatan Cross Sectional yaitu observasi faktor risiko dan variabel-variabel efek dilakukan sekaligus bersamaan (Notoatmodjo, 2010). Populasi penelitian ini adalah semua penderita hipertensi di Puskesmas Grogol periode bulan Juni sebanyak 100 penderita hipertensi. Pengambilan sampel menggunakan teknik total sampling, yaitu anggota populasi seluruhnya menjadi sampel penelitian (Sugiyono, 2017). Jadi sampel penelitian sebanyak 100 responden.

1. Kriteria Inklusi

a. Kooperatif

b. Bersedia jadi responden

2. Kriteria Eklusi
a. Penderita hipertensi dengan komplikasi lain seperti diabetes, gangguan jantung dan ginjal
b. Tidak bisa membaca dan menulis
c. Kondisi tiba-tiba jadi patologis

\section{HASIL}

1. Hasil Analisis Univariat

Tabel 1

Gambaran Karakteristik Penderita Hipertensi

\begin{tabular}{ccc}
\hline $\begin{array}{c}\text { Karakteristik } \\
\text { Responden }\end{array}$ & $\begin{array}{c}\text { Jumlah } \\
(\mathbf{n})\end{array}$ & $\begin{array}{c}\text { Persentase } \\
(\mathbf{\%})\end{array}$ \\
\hline Usia & & \\
\hline$\geq 45$ Tahun & 63 & 63,0 \\
< 45 Tahun & 37 & 37,0 \\
\hline Jenis Kelamin & & \\
\hline Laki-Laki & 67 & 67,0 \\
\hline Perempuan & 33 & 33,0 \\
\hline Lama Menderita & & \\
\hline$\geq 5$ Tahun & 60 & 60,0 \\
\hline < 5 Tahun & 40 & 30,0 \\
\hline Total & $\mathbf{1 0 0}$ & $\mathbf{1 0 0}$ \\
\hline
\end{tabular}

Berdasar Tabel 1 diketahui bahwa dari dari 100 penderita hipertensi di Wilayah Kerja Puskesmas Grogol Kota Cilegon, mayoritas $(63 \%)$ atau sebanyak 63 penderita hipertensi berusia $\geq 40$ tahun, mayoritas $(67 \%)$ atau sebanyak 67 penderita hipertensi berjenis kelamin laki-laki, dan mayoritas $(60 \%)$ atau sebanyak 60 penderita telah menderita hipertensi $\geq 5$ tahun.

Tabel 2

\begin{tabular}{ccc}
\multicolumn{3}{c}{ Gambaran Kemampuan Koping } \\
\multicolumn{3}{c}{ Pada Penderita Hipertensi } \\
\hline Kemampuan & Jumlah & $\begin{array}{c}\text { Persentase } \\
(\boldsymbol{\%})\end{array}$ \\
Koping & $(\mathbf{n})$ & 65,0 \\
Maladaptif & 65 & 35,0 \\
Adaptif & 35 & $\mathbf{1 0 0}$ \\
\hline Total & $\mathbf{1 0 0}$ &
\end{tabular}

Berdasar Tabel 2 terlihat dari 100 penderita hipertensi di Puskesmas Grogol Kota Cilegon, mayoritas (65\%) atau sebanyak 65 penderita hipertensi memiliki kemampuan koping dalam kategori maladaptif.

Tabel 3

Gambaran Kecemasan Pada Penderita Hipertensi

\begin{tabular}{ccc}
\hline Kecemasan & $\begin{array}{c}\text { Jumlah } \\
(\mathbf{n})\end{array}$ & $\begin{array}{c}\text { Persentase } \\
(\mathbf{\%})\end{array}$ \\
\hline Cemas Ringan & 27 & 27,0 \\
Cemas Sedang & 43 & 43,0 \\
Cemas Berat & 30 & 30,0 \\
\hline Total & $\mathbf{1 0 0}$ & $\mathbf{1 0 0}$ \\
\hline
\end{tabular}

Berdasar Tabel 3 terlihat dari 100 penderita hipertensi di Puskesmas Grogol Kota Cilegon, Sebagian merasakan cemas sedang sebanyak 43 penderita (43\%). 


\section{Hasil Analisis Bivariat}

Tabel 4

Hubungan Kemampuan Koping dengan Kecemasan Pada Penderita Hipertensi

\begin{tabular}{|c|c|}
\hline \multirow{3}{*}{$\begin{array}{c}\text { Kemampuan } \\
\text { Koping }\end{array}$} & Kecemasan \\
\hline & Sedang \\
\hline & Value \\
\hline Maladaptif & $\begin{array}{lllll}1,5 & 35 & 53,8 & 29 & 44,6\end{array}$ \\
\hline Adaptif & 0,000 \\
\hline Total & $\begin{array}{lll}43 & 43,0 & 30 \\
\end{array}$ \\
\hline $\begin{array}{l}\text { bahi } \\
\text { kopi } \\
\text { seba } \\
\text { kem } \\
\text { kece } \\
0,00 \\
\text { dian } \\
\text { anta } \\
\text { kece } \\
\text { Wila } \\
\text { Cile }\end{array}$ & $\begin{array}{l}\text { erdasar Tabel } 4 \text { dapat dijelaskan } \\
\text { a lansia yang memiliki kemampuan } \\
\text { g maladaptif dengan kecemasan berat } \\
\text { yak } 29 \text { orang }(44,6 \%) \text { dan } \\
\text { mpuan koping adaptif dengan } \\
\text { lasan berat sebanyak } 1 \text { orang }(2,9 \%) \text {. } \\
\text { ji statistik mendapatkan p value = } \\
\text { pada } \alpha=0,05(\mathrm{p}<\alpha) \text { maka bisa } \\
\text { il kesimpulan ada hubungan erat } \\
\text { kemampuan koping dengan tingkat } \\
\text { lasan pada penderita hipertensi di } \\
\text { ah Kerja Puskesmas Grogol Kota } \\
\text { on tahun 2021. }\end{array}$ \\
\hline
\end{tabular}

\section{PEMBAHASAN}

\section{Gambaran Usia Pada Penderita Hipertensi}

Hasil penelitian menggambarkan bahwa mayoritas penderita hipertensi di Puskesmas Grogol Kota Cilegon berusia $\geq$ 45 tahun (63\%). Hasil penelitian sesuai dengan teori mengatakan bahwa usia berpengaruh terhadap kejadian hipertensi. Usia termasuk dari faktor risiko yang tidak bisa dirubah. Seiring bertambahnya usia, elastisitas atau kelenturan arteri akan berkurang sehingga menyebabkan hipertensi meningkat.

Lubis (2018) mengatakan bahwa hipertensi pada umumnya berkembang pada usia > 40 tahun. Hal tersebut karena adanya penebalan pada dinding arteri akibat pada otot terjadi penumpukan zat kolagen, hal itu membuat menyempitnya pembuluh darah dan kaku. Seiring bertambahnya usia, mayoritas orang tekanan darahnya akan naik, TD sistolik mengalami peningkatan hingga usia 80 tahun dan TD diastolik hingga usia 55-60 tahun.

Hasil penelitian Apriyandi (2010) tentang kaitannya usia dengan kejadian hipertensi di RS Bhineka Bakti Husada Jakarta menemukan adanya hubungan signifikan antara peningkatan usia dengan

kejadian hipertensi. Hasil analisis didapatkan nilai probabilitas 0,000 $(\mathrm{p}<0.05)$.

2. Gambaran Jenis Kelamin Penderita Hipertensi

Hasil penelitian menggambarkan bahwa mayoritas penderita hipertensi di Puskesmas Grogol Kota Cilegon berjenis kelamin laki-laki (67\%).

Hasil tersebut sesuai teori dari Palmer \& William (2017) yang menyatakan jenis kelamin termasuk faktor resiko hipertensi yang tidak bisa dirubah. Terdapat perbedaan antara perempuan dan laki-laki jika dikaitkan dengan tekanan darah atau hipertensi. Jenis kelamin laki-laki lebih mudah terserang hipertensi, hal itu disebabkan perempuan memiliki perlindungan dari penyakit kardiovaskular sebelum menopause. Perempuan sebelum menopause dilindungi hormon estrogen yang memproduksi zat HDL (High Density Lipoprotein), zat tersebut bisa melindungi dari terjadinya proses aterosklerosis.

Indriyani (2015) juga menjelaskan bahwa laki-laki memiliki lebih banyak faktor yang bisa memicu kejadian hipertensi, seperti kelelahan, makan yang tidak terkontrol dan stres. Laki-laki juga cenderung tidak dapat mengontrol emosi dan memiliki lebih banyak kebiasaan kurang baik, misalnya minum alkohol dan merokok yang dapat memicu peningkatan tekanan darah.

Hasil penelitian Eksanoto (2010) di Jagalan Surakarta tentang kaitan jenis kelamin dan pendidikan dengan kejadian hipertensi menunjukkan bahwa jenis kelamin berhubungan yang signifikan dengan kejadian hipertensi (nilai p 0,000 < $0,05)$.

Kesimpulan yang didapat dari beberapa teori dan hasil penelitian diatas adalah laki-laki beresiko lebih tinggi terkena hipertensi disebabkan oleh gaya hidup laki-laki lebih buruk dibandingkan wanita, pada sebagian besar laki-laki merokok sudah menjadi kebiasaan yang sulit dihilangkan. Selain itu, pada laki-laki kurang bisa menjaga emosi ketika ada terlibat suatu masalah.

3. Gambaran Lama Menderita Pada Penderita Hipertensi 
Hasil penelitian menggambarkan bahwa mayoritas penderita hipertensi di Puskesmas Grogol Kota Cilegon menderita hipertensi $\geq 5$ tahun (60\%). Hipertensi adalah peningkatan menetap tekanan arteri sistemik. Secara umum hipertensi ialah kondisi TD tinggi persisten dimana TD sistoliknya melebihi $140 \mathrm{mmHg}$ dan TD diastoliknya melebihi $90 \mathrm{mmHg}$. Jadi bisa diartikan hipertensi sebagai peningkatan TD yang tidak normal dan terjadi berkelanjutan disebabkan oleh suatu hal tidak berjalan dengan sebagaimana mestinya (Lubis, 2018).

Lamanya seseorang menderita hipertensi dapat berpengaruh terhadap kejadian komplikasi yang lebih berat. Indriyani (2015) menyatakan bahwa hiperensi yang terjadi dalam waktu yang lama bisa meyebabkan kerusakan endothel arteri dan terjadi atherosklerosis. Hipertensi bisa menyebabkan komplikasi yang merusak organ tubuh seperti mata, otak, jantung, ginjal, serta pembuluh darah besar.

Hasil penelitian Nurimah (2018) di Dusun Pajaran Jombang menunjukkan bahwa lama menderita hipertensi berkaitan erat dengan kejadian demensia pada lansia (p value 0,000). Semakin lama lansia menderita hipertensi semakin besar resikonya untuk mengalami demensia.

Palmer \& William (2017) menyatakan bahwa hipertensi yang diabaikan dan tidak dilakukan pengobatan bisa meyebabkan gangguan pada seluruh sistem organ dan memperpendek usia harapan hidup hingga 10 sampai 20 tahun. Selain pengobatan secara farmakologi, pengendalian hipertensi bisa dilakukan dengan menerapkan pola hidup yang sehat, misalnya dengan berolahraga secara teratur, menghentikan kebiasaan merokok dan minum munuman beralkohol, mengurangi makanan berlemak, mengurangi asupan garam natrium, banyak mengkonsumsi buah dan sayur, mengontrol berat badan, menciptakan suasana rileks, menghindari stres dan lainlain. Efek dari penurunan tekanan darah bisa mencegah demensia dan penurunan kognitif serta mencegah komplikasi pada organ lain, seperti stroke, gangguan penglihatan, penyakit jantung, gagal ginjal dan pembuluh darah.

\section{Gambaran Kemampuan Koping Pada Penderita Hipertensi}

Koping merupakan cara seseorang untuk mencari solusi, mendapatkan penyelesaian masalah, beradaptasi dengan perubahan, reaksi pada situasi yang menimbulkan ancaman. Koping bisa melalui perubahan perilaku dan sudut pandang berfikir (kognitif) atau merubah lingkungan yang memiliki tujuan menyelesaikan ancaman yang dihadapi. Hasil penelitian menggambarkan mayoritas penderita hipertensi di Puskesmas Grogol Cilegon memiliki kemampuan koping maladaptif (65\%).

Kemampuan koping terbagi 2 mekanisme, yaitu adaptif dan maladaptif. Koping adaptif mengarahkan pasien untuk berperilaku konstruktif. seperti mencari informasi tentang masalah yang dihadapi atau teknik relaksasi, sehingga mampu mengatasi stressor. Sedangkan mekanisme koping maladaptif mengarahkan pasien untuk berperilaku menyimpang, seperti menghindar dari masalah, atau mencederai diri sendiri (Keliat, 2011).

Hasil penelitian tersebut menunjukkan bahwa masih banyak penderita hipertensi yang belum mampu mengelola tekanan atau stressor yang muncul akibat hipertensi yang dideritanya. Kondisi tersebut sebenarnya sangat disayangkan, karena ketidak kemampuan dalam beradapatasi atau mal adaptif dapat membuat penderita hipertensi menjadi abai dalam mengelola hipertensinya sehingga resiko terjadi komplikasi yang lebih berat akan meningkat.

Mekanisme koping adalah prilaku spontan sebagai respon pertahanan atau perlindungan psikologis terhadap peristiwa yang mengancam atau menegangkan. Mekanisme tersebut dipakai dalam upaya melindungi terhadap perasaan tidak berdaya dan kecemasan, terkadang mekanisme pertahanan diri bisa menyimpang dan tidak bisa membantu seseorang seseorang dalam menghadapi stressor. Koping yang efektif akan menghasilkan adaptasi. Koping dapat diidentifikasi melalui respons dan manifestasi (tanda dan gejala) (Stuart, 2016).

Keliat (2011) menyatakan bahwa kemampuan koping yang adaptif diperlukan 
untuk bertahan hidup di lingkungan yang selalu berubah dengan cepat. Koping merupakan pemecahan masalah dimana seseorang menggunakannya untuk mengelola kondisi stress. Untuk memiliki koping yang adaftif, seorang penderita hipertensi harus mengenali apa itu hipertensi dan cara pengelolaannya. Dengan kata lain penderita harus memiliki pengetahuan yang cukup mengenai penyakit hipertensi yang dideritanya. Dengan pengetahuan yang baik, penderita dapat membuat mekanisme dalam menyelesaikan suatu masalah, beradaptasi dengan penyakitnya, dan memiliki respons yang cepat terhadap keadaan yang mengancam yang ditimbulkan oleh penyakitnya.

Selain pengetahuan, kemampuan koping sangat dipengaruhi oleh dukungan sosial, terutama dukungan keluarga. Dukungan sosial adalah sumber koping yang kuat dan mampu mempengaruhi situasi yang dinilai stressfull. Dukungan sosial bisa membuat orang yang stres mampu mengubah situasi, mengubah arti, situasi atau mengubah reaksi emosinya terhadap situasi yang ada. Orang dengan dukungan sosial percaya bahwa mereka dihargai dan dicintai dan merupakan bagian dari jaringan sosial, hal tersebut merupakan kekuatan tersendiri dalam menghadapi stressor (Stuart, 2016).

\section{Gambaran Kecemasan Pada Penderita} Hipertensi

Kecemasan adalah sebuah gangguan pada alam perasaan yang ditandai dengan perasaan ketakutan atau kekhawatiran terhadap suatu hal, namun tidak menyebabkan gangguan dalam menilai kenyataan, kepribadian masih tetap utuh atau normal. Dalam penelitian ini kecemasan timbul akibat penyakit hipertensi yang diderita responden. Hasil penelitian menggambarkan bahwa tingkat kecemasan yang dialami penderita hipertensi di Wilayah Kerja Puskesmas Grogol Kota Cilegon bervariasi, yaitu cemas ringan sebanyak $27 \%$, cemas sedang sebanyak $43 \%$, dan cemas berat sebanyak $30 \%$. Hasil tersebut menunjukkan bahwa mayoritas penderita hipertensi mengalami cemas sedang.
Hipertensi seringkali menimbulkan kecemasan pada penderitanya. Hal tersebut disebabkan hipertensi adalah penyakit yang bisa menimbulkan banyak sekali komplikasi, seperti stroke, gagal jantung, ginjal dan semuanya bisa menyebabkan terjadinya kematian. Lewis (2011) menyatakan bahwa hipertensi disebut dengan silent killer karena terjadinya sering tanpa gejala dan bisa menimbulkan penyakit pada multi organ.

Gangguan kecemasan jangka pendek bisa berguna untuk seseorang mempersiapkan diri menghadapi krisis karena kewaspadaannya meningkat. Tetapi efek terhadap fisik bisa merugikan, seperti sering buang air, pusing, diare, dan mual. Jika kondisi tersebut berlanjut, kecemasan bisa mengganggu kesehatan mental dan fisik. Kecemasan pada penderita hipertensi berpotensi memperburuk kondisi kesehatan penderita.

Hawari (2011) menjelaskan bahwa gejala kecemasan dimanifestasikan dalam tiga gejala, yaitu gejala fisiologis, gejala emosional dan gejala kognitif. Gejala fisiologis, ditandai dengan meningkatnya frekuensi nadi, tekanan darah, peningkatan frekuensi nafas secara bergetar, gemetar, palpitasi, mual, muntah, sering berkemih, diare, insomnia, kelelahan, wajah pucat, mulut kering, badan terasa nyeri, gelisah, suhu badan meningkat dan kadang-kadang akan jatuh dan pingsan. Gejala emosional, ditandai dengan adanya rasa takut, tidak berdaya, gugup, kehilangan kepercayaan diri, kehilangan kontrol atau mudah marah, tegang dan tidak dapat rileks. Individu juga merasa cenderung menyalahkan orang lain, menarik diri, dan kurang berinisiatif. Gejala kognitif, meliputi tidak mampu berkonsentrasi, pelupa, sering termenung, ketidakmampuan untuk mengingat dan perhatian yang berlebihan.

Menurut peneliti, kecemasan pada penderita hipertensi jika tidak segera ditangani dengan baik akan menimbulkan dampak yang kurang baik, misalnya tidak patuh pada pengobatan, pengelolaan tekanan darah yang tidak efektif dan juga berpengaruh terhadap psikologis penderita, seperti dan yang berlebihan. Patimah et al., (2015) dalam penelitiannya menyebutkan bahwa dampak yang terjadi jika kecemasan 
tidak segera ditangani adalah seseorang cenderung mempunyai penilaian negatif tentang makna hidup, serta terjadi perubahan emosional seperti depresi .

6. Hubungan Kemampuan Koping dengan Kecemasan Pada Penderita Hipertensi di Puskesmas Grogol Kota Cilegon Tahun 2021

Hasil analisis hubungan antara kemampuan koping dengan tingkat kecemasan pada penderita hipertensi di Puskesmas Grogol menunjukkkan bahwa pada penderita hipertensi dengan kemampuan koping maladaptif, mayoritas merasakan cemas sedang $(53,8 \%)$ dan cemas berat $(44,6 \%)$. Sedangkan pada penderita hiperetensi dengan kemampuan koping adaptif, mayoritas hanya merasakan cemas ringan $(74,3 \%)$.

Hasil penelitian tersebut menunjukkan bahwa penderita hipertensi dengan kemampuan koping maladaptif lebih tinggi tingkat kecemasannya dibandingkan dengan penderita hipertensi yang memiliki kemampuan koping adaptif. Hasil uji statistik diperoleh $\mathrm{p}$ value $=0,000$, pada $\alpha=$ $0,05(\mathrm{p}<\alpha)$ maka dapat disimpulkan bahwa terdapat hubungan yang signifikan antara kemampuan koping dengan tingkat kecemasan pada penderita hipertensi di Wilayah Kerja Puskesmas Grogol Kota Cilegon tahun 2021.

Hasil ini sesuai teori Stuart (2016) yang menjelaskan bahwa mekanisme koping adalah cara yang dilakukan individu dalam menyelesaikan masalah, menyesuaikan diri dengan perubahan, serta respon terhadap situasi yang sedang dihadapinya. Mekanisme koping adaptif mengarahkan pasien berperilaku konstruktif. yang mampu mengatasi stressor dan kecemasan. Sedangkan mekanisme koping maladaptif mengarahkan pasien berperilaku menyimpang, menghindar dan mencederai diri sendiri. Tingkat kecemasan dipengaruhi oleh kemampuan koping masing-masing individu.

Hasil penelitian ini juga sejalan dengan hasil penelitian Kusyati (2018) di Wates Yogyakarta yang mendapatkan hasil ada kaitan antara mekanisme koping dengan tingkat kecemasan dengan nilai $\mathrm{p}$ sebesar 0,014. Demikian juga dengan hasil penelitian (Ransun, 2013) di Manado yang menunjukkan bahwa tingkat kecemasan berhubungan dengan mekanisme koping pasien gagal jantung kongestif ( $\mathrm{p}$ value: $0,004)$.

Menurut peneliti, adanya hubungan antara kemampuan koping dengan kecemasan pada penderita hipertensi disebabkan kemampuan koping berpengaruh terhadap tindakan yang dilakukan penderita dalam mengelola hipertensinya. Kemampuan koping yang adaptif membuat penderita mampu mengenali penyakit hipertensi yang dideritanya, sehingga mampu mengelola hipertensinya dengan baik. Dengan kemampuan koping yang adaptif membuat penderita tidak merasa khawatir atau cemas dengan hipertensinya, karena merasa mampu menanganinya.

\section{KESIMPULAN}

Gambaran penderita Hipertensi di Wilayah Kerja Puskesmas Grogol Kota Cilegon mayoritas berusia $\geq 45$ tahun (63\%), mayoritas berjenis kelamin laki-laki (67\%), mayoritas menderita hipertensi $\geq 5$ tahun (60\%), mayoritas memiliki kemampuan koping maladaptif $(65 \%)$, dan mayoritas mengalami cemas sedang (43\%).Terdapat hubungan yang bermakna antara kemampuan koping dengan kecemasan pada penderita hipertensi di Wilayah Kerja Puskesmas Grogol Kota Cilegon tahun 2021 (p value: 0,000).

Penderita hipertensi dapat meningkatkan pengetahuan penderita hipertensi melalui kegiatan penyuluhan dan konseling tentang hipertensi dan pengelolaannya secara berkala. Melakukan pemeriksaan kesehatan secara berkala bagi penderita hipertensi untuk mengontrol tekanan darahnya, sehingga kecemasan pada penderita hipertensi dapat dikurangi.

\section{DAFTAR PUSTAKA}

Abdul, N., \& Abdul, M. (2011). Dasar-dasar Keperawatan Jiwa. Salemba Medika.

Apriyandi. (2010). Hubungan Peningkatan Usia Dengan Kejadian Hipertensi Pada Pasien 
Yang Berobat Jalan di Rumah Sakit Bhineka Bakti Husada Jakarta. Jurnal Kesehatan UIN Syarif Hidayatullah, 1, 12-19.

Banten, D. K. (2016). Profil Kesehatan Provinsi Banten Tahun 2016. Dinas Kesehatan Provinsi Banten.

Brigita, Fima, \& Nova. (2020). Faktor-faktor yang Berhubungan dengan Kejadian Hipertensi pada Guru Sekolah Dasar di Kecamatan Tombariri Timur. KESMAS, 9(1), 189-196.

Dinas Kesehatan Daerah Provinsi Sulawesi Utara. (2018). Profil Kesehatan Provinsi Sulawesi Utara. Dinas Provinsi Sulawesi Utara.

Eksanoto. (2010). Hubungan Tingkat Pendidikan dan Jenis Kelamin Dengan Kejadian Hipertensi di Kelurahan Jagalan Wilayah Kerja Puskesmas Pucangsawit Surakarta. Jurnal Keperawatan STIKes Aisyiyah.

Hardiyanis. (2014). Hubungan Hipertensi dengan Tingkat Kecemasan di Poli Penyakit Dalam dan Poli Jantung RSUD DR.Zainal Abidin Banda Aceh. Universitas Syiah Kuala Banda Aceh.

Hawari. (2011). Depresi dalam Manajemen Stress, Kecemasan, Depresi. FKUI.

Indriyani. (2015). Deteksi Dini Kolesterol, Hipertensi, dan Stroke (Millestone).

Karo, S. K. (2016). Cegah Dan Atasi Penyakit Jantung Dan Pembuluh Darah. Praninta Aksara.

Keliat. (2011). Keperawatan Kesehatan Jiwa Komunitas CMHN (basic course). EGC.

Kemenkes RI. (2018). Riset Kesehatan Dasar.

Kozier, \& Barbara. (2011). Buku Ajar Fundamental Keperawatan Konsep, Proses dan Praktek (VII). EGC.

Kusyati, E. (2018). Hubungan Antara Mekanisme Koping dengan Tingkat
Kecemasan Pasien Gagal Ginjal Kronik Yang Menjalani Hemodialisis di RSUD Wates. Universitas Jenderal Achmad Yani Yogyakarta.

Lesmana, D. (2014). Kecerdasan Spiritual dengan Kecemasan Menghadapi Masa Pensiun. JIPT, 2(1), 168-183.

Lewis. (2011). Medical Surgical Nursing: Assesment and Management of Clinical Problems. Elsevier.

Lubis. (2018). Hipertensi dan Ginjal. USU Press.

Notoatmodjo. (2010). Metodologi penelitian kesehatan edisi revisi (Edisi Revi). Rineka Cipta.

Nuraini, \& Bianti. (2015). Risk Factors Of Hypertension. Jurnal Majority, 4(5), 1019.

Nurarif, A. H., \& Kusuma, H. (2015). Aplikasi Asuhan Keperawatan Berdasarkan Diagnosa Medis \& NANDA NIC-NOC (Jilid 2). Medi Action Publishing.

Nurimah, P. (2018). Hubungan Lama Menderita Hipertensi dengan Kejadian Demensia Pada Lansia. Jurnal Kesehatan STIKES Insan Cendekia, 1, 20-29.

Palmer, \& William. (2017). Tekanan Darah Tinggi (E. Yasmine (ed.)). Erlangga.

Patimah, Suryani, \& Nuraeni. (2015). Pengaruh relaksasi dzikir terhadap tingkat kecemasan pasien gagal ginjal kronis yang menjalani hemodialisa. Padjajaran Nursing Journal, 3, 1.

Ransun. (2013). Hubungan Tingkat Kecemasan dengan Mekanisme Koping pada Pasien Gagal Jantung Kongestif di Irina F BLU RSUP Prof. Dr. R.D. Kandou Manado. JUIPERDO, $2,1$.

Ridwan, Widodo, Dyah, Widiani, \& Esti. (2017). Hubungan Hipertensi dengan Kecemasan pada Lanjut Usia di Posyandu Permadi Kelurahan Tlogomas Kecamatan Lowokwaru Kota Malang. Bursing News, 
Adi Husada Nursing Journal, Vol. 7 No. 2, Desember 2021 / Hal. 106 https://doi.org/10.37036/ahnj.v7i1.206

2(3), 676-686.

Stuart. (2016). Prinsip dan Praktik Keperawatan Kesehatan Jiwa. Elsivier.

Sugiyono. (2017). Metode Penelitian Kuantitatif, Kuyalitatif, dan $R \& D$. Alfabeta.

Tamako. (2016). Gambaran Konsumsi Makanan Laut Penderita Hipertensi di Wilayah Kerja Puskesmas Dagho Kecamatan Tamako. Jurnal Keperawatan, 4(1).

Ummi, K., \& Giri, W. (2018). Hubungan Hipertensi dengan Tingkat Kecemasan pada Lansi di Panti Sosial Tresna Wredha Budi Mulia 2 Cengkareng Jakarta Barat Tahun 2018.

WHO. (2013). A Global Brief On Hypertension: Silent Killer, Global Public Health Crises. WHO. 